\title{
Chemical Compositon of Three Microalgae Species for Possible Use in Mariculture
}

\author{
Alfredo Matos Moura Junior ${ }^{1}$, Egídio Bezerra Neto ${ }^{2}$, Maria Luise Koening ${ }^{3}$ and Enide Eskinazi \\ Leça $^{4}$ \\ ${ }^{l}$ Colégio de Aplicação; Universidade Federal de Pernambuco; Av. Acadêmico Hélio Ramos, s/n; Cidade \\ Universitária; alfmoura2002@yahoo.com.br; Recife - PE - Brasil. ${ }^{2}$ Departamento de Química; Universidade \\ Federal Rural de Pernambuco; Recife - PE - Brasil. ${ }^{3}$ Departamento de Oceanografia; Universidade Federal de \\ Pernambuco; Recife - PE - Brasil. ${ }^{4}$ Programa de Pós-Graduação em Botânica; Universidade Federal Rural de \\ Pernambuco; Recife - PE - Brasil
}

\begin{abstract}
The purpose of this study was to determine the chemical composition of Chaetoceros gracilis, Cylindrotheca closterium and Tetraselmis gracilis, species frequently used as food for aquaculture in the northeast of Brazil. The species were grown in f/2 medium, in carboys, aerated from one liter, with constant illumination and analyses were made in late exponential growth phase. Cellular density $\left(8,447 \times 10^{6}{ }^{6}\right.$ cell. $\left.L^{-1}\right)$, soluble carbohydrates $(0.10 \pm 0.01$ $\left.\mathrm{mg} . \mathrm{L}^{-1}\right)$ and magnesium $\left(14.78 \pm 0.08 \mathrm{mg} . \mathrm{L}^{-1}\right)$ were the highest in $\mathrm{C}$. gracilis. $\mathrm{C}$. closterium had the highest amount of chlorophyll a $\left(13.76 \pm 1.11 \mathrm{mg} \cdot \mathrm{L}^{-1}\right)$, soluble proteins $\left(0.62 \pm 0.04 \mathrm{mg} \cdot \mathrm{L}^{-1}\right)$, total amino acids $\left(23.82 \pm 0.84 \mathrm{mg} . \mathrm{L}^{-1}\right)$, nitrate $\left(0.36 \pm 0.02 \mathrm{mg} . \mathrm{L}^{-1}\right)$, sodium $\left(0.46 \pm 0.05 \mathrm{mg} . \mathrm{L}^{-1}\right)$ and phosphorus $\left(2.80 \pm 0.38 \mathrm{mg} . \mathrm{L}^{-1}\right)$. Both the species had potassium levels of $0.02 \mathrm{mg} . \mathrm{L}^{-1}$ and sulfur levels of $0.03 \mathrm{mg} . \mathrm{L}^{-1}$. T. gracilis had the lowest values in almost all the analyzed variables, except for chlorophyll a. Therefore, among the analyzed species and tested conditions, C. closterium represented the best nutritional option for aquaculture projects.
\end{abstract}

Key words: Chaetoceros gracilis, Cylindrotheca closterium, Tetraselmis gracilis, chemical composition

\section{INTRODUCTION}

With the development of aquaculture in the world and the necessity to increase the animals survival in culture, studies have shown the importance of food production for cultivated species development. Knowledge of the natural feeding habits and digestive system of organisms is an essential factor for the attainment of high productivity in an aquaculture setting. This, in turn, depends on the food efficiency of different trophic levels (Sipaúba-Tavares and Rocha, 2001). The importance of the success of unialgae mass cultures consists in the great variety of fields, such as genetic, cytology, taxonomy and plant physiology, that can utilize this resource (Sukenik and Whanon, 1991; Fidalgo et al., 1998; Renaud et al., 1999).

Microalgae chemical composition is frequently determined with the objective to provide the necessary nutritional balance for the captive animals (Whyte, 1987; Brown et al. 1997, 1998 Southgate et al., 1998;; Caers et al., 1999; McCausland et al., 1999), and also to determine the biochemical variation of the microalgae composition with respect to the nutritional

\footnotetext{
${ }^{*}$ Author for correspondence
} 
medium in which the microalgae are being cultivated (Antia et al., 1977; Fabregas et al., 1985a and b, 1986; Melo et al., 1993; Lourenço et al., 1997).

In Brazil, the studies about microalgae chemical composition are recent and limited to studies about alternative culture mediums (Koening et al., 1990a, 1998; Melo et al., 1993) or to the comparisons of the microalgae chemical composition in relation to the nutritional medium (Koening, 1990b; Lourenço et al., 1998). Considering the substantial growth of aquaculture activities in Brazil (8\% increase per year), according to Sipaúba-Tavares and Rocha (2001), it is necessary to increase the studies about microalgae nutritional value. The purpose of this work was to determine the chemical composition of Chaetoceros gracilis, Cylindrotheca closterium and Tetraselmis gracilis, three widely used microalgae for the feeding of aquaculture fish and shrimp in the northeast region of Brazil. The results of this study will aid aquaculture farmers in choosing microalgae for its nutritional value.

\section{MATERIAL AND METHODS}

Chaetoceros gracilis, Cylindrotheca closterium and Tetraselmis gracilis were cultivated in triplicate. Cultures were placed in aerated carboys (8 L) filled with f/2-Guillard medium (Guillard, 1975). Two daylight fluorescent tubes of $20 \mathrm{~W}$ were used to maintain constant illumination and culture temperature was $22 \pm 1^{\circ} \mathrm{C}$. The experiments started with microalgae culture in the exponential growth phase and were kept in $10 \mathrm{~mL}$ assay pipes, with the same light, temperature and culture medium conditions. The three species were inoculated in $250 \mathrm{~mL}$ glass bottles with $\mathrm{f} / 2$ Guillard medium. Every eight days, this volume was duplicated with autoclaved seawater $(1 \mathrm{~atm}$ for $1 \mathrm{~h}$ ) and enriched with the same components of the $\mathrm{f} / 2$ medium until the total of 8 liters of culture was reached. After eight days the cultures were harvested for the chemical analyses.

Cellular density was counted daily for the first eight days of the experiment to determine the growth of each microalgae. The final cellular density was determined at the end of the experiment. These analyses were performed using a binocular Zeiss microscope, with Neubauer chambers from samples preserved with $4 \%$ buffered formaldehyde. The cellular density result was presented as cell. $L^{-1}$.

Chlorophyll $a$ was determined according to Becker (1995). Three replicates from each species were filtered in Whatmann GF/F fiberglass filters (diameter $=47 \mathrm{~mm})$, extracted with $90 \%$ acetone and analyzed with a spectrophotometer. The remaining part of each culture was centrifuged at $7,000 \mathrm{rpm}$ for 15 minutes. The centrifuged material was collected and dried in an oven (60 ${ }^{\circ} \mathrm{C}$ ) until constant weight, according to Bezerra Neto et al. (1994).

For soluble carbohydrate, soluble protein and nitrate determinations, $1.0 \mathrm{~g}$ of dried, preweighed microalgae and $10 \mathrm{~mL}$ of distilled water were used to prepare an extract. The soluble carbohydrate was determined according to Yemm and Wills (1954). For this, a $200 \mu \mathrm{L}$ sample of the extract was transferred to an assay tube. Then, $2 \mathrm{~mL}$ of the anthrone reagent was added for the color development, with the tubes placed in a hot water bath at $100^{\circ} \mathrm{C}$, for 10 minutes to develop the color. The samples were then analyzed at $620 \mathrm{~nm}$ in a spectrophotometer and compared with standard glucose solution (concentration from 0 to 300 mg. $L^{-1}$ ).

Soluble protein was determined according to Bradford (1976). Samples (100 $\mu \mathrm{L})$ were collected from the microalgae extracts and transferred to assay tubes, which contained $2.0 \mathrm{~mL}$ of the Coomassie brillant blue reagent. After color development, spectrophotometric readings at 595 $\mathrm{nm}$ were determined and compared with the results from solutions of bovine albumen standards (BSA) in concentration from 0 to $200 \mathrm{mg} \cdot \mathrm{L}^{-1}$. Free total amino acids were determined according to Yemm and Cocking (1955).

Nitrate analysis was carried out according to Cataldo et al. (1975). From each extract, $200 \mu \mathrm{L}$ was transferred to assay tubes and $800 \mu \mathrm{L}$ of salicilic acid reagent $\left(5 \% \mathrm{H}_{2} \mathrm{SO}_{4}\right)$ was added to each assay tube. Twenty minutes later, $18 \mathrm{~mL}$ of $\mathrm{NaOH}(2 \mathrm{~N})$ was added to the sample. Spectrophotometric readings at $410 \mathrm{~nm}$ were determined. Results were compared with standard nitrate solution in concentration from 0 to 300 mg. $L^{-1}$.

Sodium and magnesium were determined by the atomic absorption spectrophotometry as described by Malavolta et al. (1989). Sulphur was determined by the turbidimetry according to Sarruge and Haag (1974). Phosphorus was 
measured by molibdo-vanadato of ammonium colorimetric method and potassium was determined in a flame photometer, according to Bezerra Neto et al. (1994).

Data were treated statistically by the analysis of variance (ANOVA) with $\propto=0.05$. Additionally, a

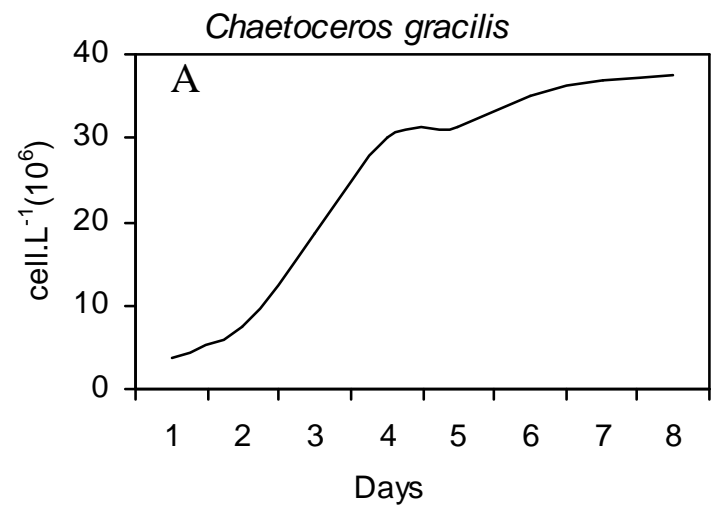

Tukey test was performed and ran in the SANEST program (Sarriés et al., 1992).

Figure 1 - Growth curves of Chaetoceros gracilis (A) and Tetraselmis gracilis (B) cultivated in $\mathrm{f} / 2$ Guillard medium during the first eight days of the experiment.

\section{RESULTS AND DISCUSSION}

\section{Cellular density}

Chaetoceros gracilis, Cylindrotheca closterium and Tetraselmis gracilis have been used successfully as a nourishing source for a variety of clams and other organisms (Sukenik and Wahnon, 1991; McCausland et al., 1999). The growth curves for $C$. gracilis and $T$. gracilis from the present study are presented in Figure 1A and 1B. A cell count for $C$. closterium could not be accurately determined because of cell clumping. This difficulty was also noted by Brown (1991).

C. gracilis cellular density at the end of the culture cycle presented the best result, reaching $8,442 \pm 7.07 \times 10^{6}$ cell. $\mathrm{L}^{-1}$, while $T$. gracilis reached $562 \pm 19.45 \times 10^{6}$ cell. $\mathrm{L}^{-1}$, with a significant difference between species $(\mathrm{P}<0.05)$. Similar cellular density values for $C$. gracilis (95$6,415 \times 10^{6}$ cell..$L^{-1}$ ) were also determined by Yamashita and Magalhães (1984) using FeNS as the growth medium. Lourenço et al. (1997) cultivating $T$. gracilis in Conway medium, found highest cellular density values $\left(1,71 \times 10^{9}\right.$ cell. $\left.\mathrm{L}^{-1}\right)$. The high densities were probably because Conway medium was more nutritive than f2-Guillard.

\section{Chemical composition}

One of the best parameters to monitor microalgae production is the estimation of growth, generally expressed in biomass and density increase, proteins, pigments, carbohydrates contents over a certain period of time (Becker, 1995). As it happens in any superior vegetable, microalgae biomass and chemical composition can vary according to environment conditions and the age of the culture (Lourenço et al., 1998; Renaud et al., 1999; Araújo, et al., 2005). In C. gracilis cultures, $\mathrm{pH}$ varied from 7.7 to 9.5 and from 7.5 to 10 in $T$. gracilis cultures.

The highest chlorophyll $a$ mean value was found in C. closterium $\left(13.76 \pm 1.1 \mathrm{mg} . \mathrm{L}^{-1}\right)$, followed by T. gracilis $\left(7.12 \pm 0.61 \mathrm{mg} . \mathrm{L}^{-1}\right)$ and $C$. gracilis (3.28 $\left.\pm 0.82 \mathrm{mg} . \mathrm{L}^{-1}\right)$, with significant differences among the species $(\mathrm{P}<0.05)$ (Figure $2 \mathrm{~A})$. These values were higher than those found by Lourenço et al. (1997), who cultivated T. gracilis in Conway medium (1.51-3.57 mg. $\mathrm{L}^{-1}$ ) and by Brown (1991), who cultivated $C$. gracilis in $\mathrm{f} / 2\left(0.78 \mathrm{pg}^{-\mathrm{cel}^{-1}}\right.$ or $\left.1.48 \mathrm{mg} \cdot \mathrm{L}^{-1}\right)$. High chlorophyll $a$ values were probably due to the high cell density, which diminished irradiation inside the carboy, leading to the increased production of chlorophyll $a$ (LópezMuñoz et al., 1992; Sauodi-Helis et al., 1999; Valenzuela-Espinoza et al., 2002).

C. gracilis had the highest amount of soluble carbohydrates, with a value of $0.1 \pm 0.01 \mathrm{mg} . \mathrm{L}^{-1}$, followed by $C$. closterium $\left(0.09 \pm 0.01 \mathrm{mg} . \mathrm{L}^{-1}\right)$ and T. gracilis $\left(0.06 \pm 0.01 \mathrm{mg} . \mathrm{L}^{-1}\right)$, with significant differences between the first two $(\mathrm{P}<0.05)$ (Figure 
2B). These values were considered low for the analyzed culture phase (final exponential phase where the species tended to accumulate carbohydrates), due to nitrogen limitation during the log phase for the protein synthesis, reducing the amount of soluble protein, as also observed by Brown (1991), Brown et al. (1997) and Renaud et al. (1999). This was also observed in this work in relation to soluble protein (Figure 2C), where the highest value was found in $C$. closterium $\left(0.62 \pm 0.04 \mathrm{mg} . \mathrm{L}^{-1}\right)$, followed by $C$. gracilis $\left(0.58 \pm 0.02 \mathrm{mg} . \mathrm{L}^{-1}\right)$ and $T$. gracilis $(0.38 \pm 0.04$ mg. $\left.\mathrm{L}^{-1}\right)$. There was a significant difference between the first two and the third $(\mathrm{P}<0.05)$.

The total free amino acid also showed this trend (Figure 2D), with significant differences among the species $(\mathrm{P}<0.05)(C$. closterium: $23.28 \pm 0.84$ mg. $\mathrm{L}^{-1}$, C. gracilis: $15.25 \pm 1.40 \mathrm{mg} . \mathrm{L}^{-1}$, T. gracilis: $\left.1.49 \pm 0.12 \mathrm{mg} . \mathrm{L}^{-1}\right)$. These values were lower than those obtained by Fabregas et al. (1985b), whose mass culture of $T$. suecica was found to have a maximum protein value of $306 \mathrm{mg} \mathrm{L}^{-1}$ in logarithmic culture phase. Koening et al. (1990b) determined the chemical composition of $T$. tetrathele using organic fertilizer as the medium. They observed that under these conditions, the soluble protein amount was $310 \mathrm{mg} \cdot \mathrm{L}^{-1}$.

C. closterium had the highest values for nitrate $\left(0.36 \pm 0.02 \mathrm{mg} . \mathrm{L}^{-1}\right)$, sodium $\left(0.46 \pm 0.05 \mathrm{mg} . \mathrm{L}^{-1}\right)$ and phosphorous $\left(2.80 \pm 0.38 \mathrm{mg} . \mathrm{L}^{-1}\right)$. Nitrate values for $C$. closterium were significantly different from the other two species $(\mathrm{P}<0.05)$ and sodium values were significantly different among the species $(\mathrm{P}<0.05)$. C. closterium phosphorus values were different significantly from $T$. gracilis $(\mathrm{P}<0.05)$. Potassium content $\left(0.02 \mathrm{mg} . \mathrm{L}^{-1}\right)$ and sulphur content $\left(0.03 \mathrm{mg} . \mathrm{L}^{-1}\right)$ were equal for $C$. gracilis and C. closterium. T. gracilis showed lower inorganic nutrient content, with a significant difference in potassium levels $(\mathrm{P}<0.05)$ (Table 2$)$. As the present study showed, there were differences in the chemical composition among these three microalgal species, even when cultivated under the same conditions. These differences could be related to specific differences in the cell metabolism and therefore resulted in a variation of the chemical balance of chlorophyll $a$, proteins, carbohydrates and minerals. These factors, when associated to other chemical components, such as vitamins, were essential in promoting the herbivorous growth (Chu et al., 1982; Webb and Chu, 1983; Brown et al., 1998).

\section{CONCLUSION}

The microalgae $C$. gracilis, C. closterium and T. gracilis, when cultured in $\mathrm{f} / 2$-Guillard medium, in carboy, showed quantitative differences in chemical composition and biomass. These variations were observed in chlorophyll $a$, soluble proteins, carbohydrates, free total amino acids, mineral content and cellular density. T. gracilis presented lower results, producing significantly lower values in the majority of the analyzed parameters. With regards to chlorophyll $a$, soluble protein and carbohydrates, C. closterium showed the highest results. It also showed a significantly higher nitrate amount. According to the chemical parameters analyzed and tested conditions, $C$. closterium was the best nutritional option for aquaculture. 

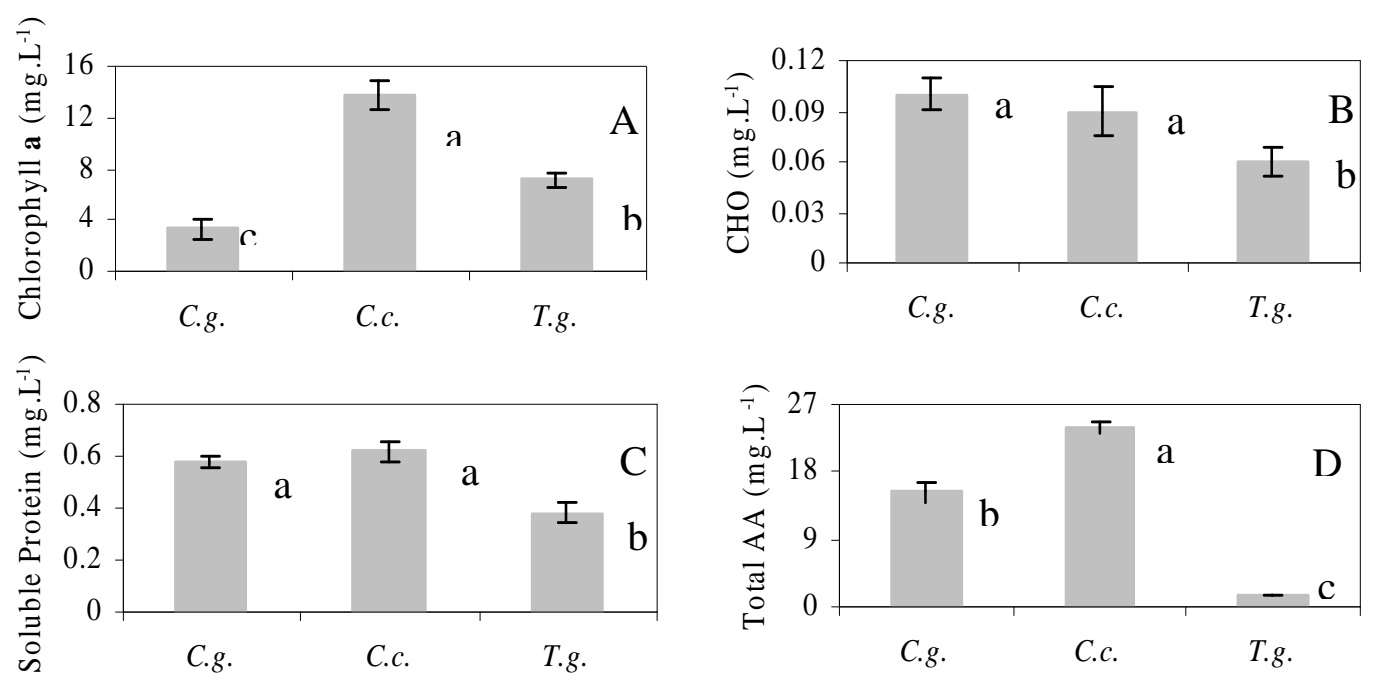

Figure 2 - Amounts of chlorophyll a (A), soluble carbohydrates - CHO - (B), soluble proteins (C) and free total amino acids - Total AA - (D) in three microalgae species cultured in carboys with f/2 - Guillard medium. C.g. - Chaetoceros gracilis; C.c. - Cylindrotheca closterium; T.g. - Tetraselmis gracilis. The same superscript letters in columns indicate means which do not differ significantly from each other $(\mathrm{P}<0.05)$.

Table 1 - Inorganic nutrient average values ( \pm s.d.) for Chaetoceros gracilis, Cylindrotheca closterium and Tetraselmis gracilis cultured in carboys wtih $\mathrm{f} / 2$ - Guillard medium.

\begin{tabular}{lccc}
\hline & $\begin{array}{c}\text { Chaetoceros gracilis } \\
\text { mg. }^{-1}\end{array}$ & $\begin{array}{c}\text { Cylindrotheca closterium } \\
\text { mg. }^{-1}\end{array}$ & $\begin{array}{c}\text { Tetraselmis gracilis } \\
\text { mg. }^{-1}\end{array}$ \\
\hline Nitrate & $0.13 \pm 0.04^{\mathrm{b}}$ & $0.36 \pm 0.02^{\mathrm{a}}$ & $0.08 \pm 0.01^{\mathrm{b}}$ \\
Sodium & $0.07^{\mathrm{a}}$ & $0.46 \pm 0.05^{\mathrm{b}}$ & $0.03^{\mathrm{c}}$ \\
Potassium & $0.02^{\mathrm{a}}$ & $0.02^{\mathrm{a}}$ & $0.01^{\mathrm{b}}$ \\
Phosphorus & $2.09 \pm 0.02^{\mathrm{a}}$ & $2.80 \pm 0.39^{\mathrm{a}}$ & $0.95 \pm 0.16^{\mathrm{b}}$ \\
Magnesia & $14.78 \pm 0.08^{\mathrm{a}}$ & $4.97 \pm 0.06^{\mathrm{a}}$ & $6.95 \pm 0.30^{\mathrm{a}}$ \\
Sulphur & $0.03^{\mathrm{a}}$ & $0.03^{\mathrm{a}}$ & $0.01^{\mathrm{a}}$ \\
\hline
\end{tabular}

The same superscript letters in columns indicate means which do not differ significantly from each other $(\mathrm{P}<0.05)$.

\section{ACKNOWLEDGEMENTS}

We thank Conselho Nacional de Desenvolvimento Científico e Tecnológico (CNPq) for two years of scholarship for the first author and we appreciate the use of the laboratory facilities at Rural Federal University of Pernambuco and Federal University of Pernambuco.

\section{RESUMO}

Este trabalho objetivou a determinação da composição química de Chaetoceros gracilis, Cylindrotheca closterium e Tetraselmis gracilis, espécies de freqüente uso na aqüicultura no Nordeste do Brasil. As espécies foram cultivadas em meio f/2-Guillard, em garrafão de vidro, aeradas a partir de um litro, com iluminação constante e as análises foram realizadas no final da fase exponencial. $C$. gracilis apresentou maior densidade celular, chegando a $8.442 \times 10^{6}$ cel. $\mathrm{L}^{-1}$, o maior valor para carboidratos solúveis $(0,10 \pm 0,01$ 
mg. $\left.\mathrm{L}^{-1}\right)$ e magnésio $\left(14,78 \pm 0,08 \mathrm{mg} \cdot \mathrm{L}^{-1}\right) . C$. closterium apresentou a maior concentração para clorofila $a\left(13,76 \pm 1,11 \mathrm{mg} \cdot \mathrm{L}^{-1}\right)$, proteína solúvel $\left(0,62 \pm 0,04 \mathrm{mg} \cdot \mathrm{L}^{-1}\right)$, aminoácidos totais livres $\left(23,82 \pm 0,84 \mathrm{mg} \cdot \mathrm{L}^{-1}\right)$, nitrato $\left(0,36 \pm 0,02 \mathrm{mg} \cdot \mathrm{L}^{-1}\right)$, sódio $\left(0,46 \pm 0,05 \mathrm{mg} \cdot \mathrm{L}^{-1}\right)$ e fósforo $(2,80 \pm 0,38$ $\left.\mathrm{mg} \cdot \mathrm{L}^{-1}\right)$. Os teores de potássio $\left(0,02 \mathrm{mg} \cdot \mathrm{L}^{-1}\right)$ e enxofre $\left(0,03 \mathrm{mg} \cdot \mathrm{L}^{-1}\right)$ foram iguais para $C$. gracilis e $C$. closterium. A espécie $T$. gracilis apresentou os menores valores nas variáveis analisadas, exceto para clorofila $a$. Apresentando-se, portanto, entre as três espécies analisadas, $C$. closterium como a melhor opção nutricional, dentre as condições observadas, para projetos em aqüicultura.

\section{REFERENCES}

Antia, N. J.; Berland, B. R.; Bonin, D. J. and Maestrini, S. E. (1977), Effects of urea concentration in supporting growth of certain marine microplanktonic algae. Phycol. 16:(1), 105-111.

Araújo, S. C. and Garcia, V. M. T. (2005), Growth and biochemical composition of the diatom Chaetoceros cf. wighamii brightwell under different temperatures, salinity and carbon dioxide levels. I. Protein, carbohydrates and lipids. Aquacul., 246, 405-412.

Becker, E. W. (1995), Microalgae: biotechnology and microbiology, Cambridge University Press, New York.

Bezerra Neto, E.; Andrade A. G.; Barreto L. P. (1994), Análise química de tecidos e produtos vegetais, Recife, UFRPE.

Bradford, M. M. (1976), A rapid and sensitive method for the quantitation of microgram quantities of protein utilizing the principles of protein-dye binding, Analy. Biochem. 72, 248-254.

Brown, M. R. (1991), The amino-acid and sugar composition of 16 species of microalgae used in mariculture, J. Exp. Biol. Ecol.145, 79-99.

Brown, M. R.; Jeffrey S. W.; Volkman J. K. and Dunstan G. A. (1997), Nutritional properties of microalgae for mariculture, Aquacul. 151, 315-331.

Brown, M. R.; Mc Mcausland, M. A. and Kowalski, K. (1998), The nutritional value of four Australian microalgal strains fed to Pacific oyster Crassostrea gigas spat. Aquacul.165, 281-293.

Caers, M.; Coutteau, P. and Sorgeloos, P. (1999), Dietary impact of algal and artificial diets, fed at different rations, on the growth and fatty acid composition of Tapes philippinarum (L.) spat. Aquacul. 170, 307-322.

Cataldo, D. A.; Harron, M.; Schrader, L. and Youngs, V. L. (1975), Rapid colorimetric determination of nitrate in plant and tissue by nitration of salicilic acid, Commun. Soil Science and Plant Analysis 6, 71-80.
Chu, F. L. E.; Dupuy, J. L. and Webb, K. L. (1982), Polysaccharide composition of five algal species used as food for larvae of the american oyster, Crassostrea virginica. Aquacul. 29:(3/4), 241-252.

Fabregas, J.; Herrero, C.; Abalde, J. and Cabezas, B. (1985a), Growth, chlorophyll $a$ and protein of the marine microalga Isochryrsis galbana in batch cultures with different salinities and high nutrient concentrations, Aquacul. 50, 1-11.

Fabregas, J.; Herrero, C.; Cabezas, B. and Abalde, J. (1985b), Mass culture and biochemical variability of the marine microalga Tetraselmis suecica (Kylin) Butch with high nutrients concentrations. Aquacul. 49, 231-244.

Fabregas, J.; Herrero, C.; Cabezas, B. and Abalde, J. (1986), Biomass production and biochemical composition in mass cultures of the marine microalga Isochrysis galbana Parke at varying nutrient concentrations. Aquacul. 53, 101-113.

Fidalgo J. P.; Cid, A.; Torres, E.; Sukenik, A. and Herrero, C. (1998), Effects of nitrogen source and growth phase on proximate biochemical composition, lipid classes and fatty acid profile of the marine microalga Isochrysis galbana. Aquacul. 166, 105-116.

Guillard, R. L. (1975), Culture of phytoplankton for feeding marine invertebrates. Culture of marine invertebrate animal, p. 29-60.

Koening, M. L.; Lacerda, S. R. and Passavante, J. Z. O. (1990a), Cultivo em laboratório de Tetraselmis chuii e Tetraselmis tetrathele (Chlorophyceae) com fertilizantes orgânicos. Arq. Biolog. Tecnolog. 33, 91103.

Koening, M. L.; Maia, P. R. and Campos-Takaki, G. M. (1990b), Composição bioquímica de Tetraselmis tetrathele (West. G. S) Butcher (Chlorophyceae) cultivada com fertilizante orgânico. Revist. Biol. Bras. 2, 23-38.

Koening, M. L.; Passavante, J. Z. O.; Bartolomeu, C. C. and Costa, K. M. P. (1998), O vinhoto no cultivo de microalgas. Gayana 45, 253-263.

Lopes-Muñoz, I.; Abalde, J. and Hererro, C. (1992), Crescimiento y contenido de pigmentos de cuatro especies de microalgas marinas cultivadas com diferentes temperaturas e intensidades de luz. Nov. A. Cient. Comp. 3, 59-65.

Lourenço, S. O.; Marquez, U. M. L.; Mancini-Filho, J.; Aidar, E. and Barbarino E. (1998), Distribution of intracellular nitrogen in marine microalgae: basis for the calculation of specific nitrogen-to-protein conversion factors. J. Phycol. 34, 798-811.

Lourenço, S. O.; Marquez, U. M. L.; Mancini-Filho, J.; Barbarino, E. and Aidar, E. (1997), Changes in biochemical profile of Tetraselmis gracilis I. Comparision of two culture media. Aquacul. 148, 153-158. 
Malavolta, E.; Vitti, G. and Oliviera, S. A. (1989), Avaliação do estado nutricional das plantas: Princípios e aplicações. Associação Brasileira para Pesquisa da Potassa e do Fosfato, Piracicaba.

McCausland, M. A.; Brown, M. R.; Barrett, S. M.; Diemaar, J. A. and Heasmn, M. P. (1999), Evaluation of live microalgae and miroalgae pastes as supplementary food for juvenile Pacific oysters (Crassostrea gigas). Aquacul., 174, 323-342.

Melo, G. N.; Sassi, R. and Araújo, T. F. H. (1993), Crescimento de Phaeodactylum tricornutum BOHLIN (Bacillariophyta) em água do mar enriquecida com soluções derivadas da decomposição de algas arribadas com meio de cultura. R. Nord. de Bio. 8, 4553.

Renaud, S. M.; Thinh, L. and Parry, D. L. (1999), The gross chemical composition and fatty acid composition of 18 species of tropical Australian microalgae for possible use in mariculture. Aquacul. 170, 147-159.

Sarriés, G. A.; Oliveira, J. C. V. and Alves, M. C. (1992), SANEST, Série didática $\mathrm{n}^{\circ}$ 06, Centro de Informática da Universidade de São Paulo, Piracicaba.

Sarruge, J. R. S. and Haag, H. P. (1974), Análises Químicas em Plantas, Piracicaba, USP-ESALQ.

Sauodi-Helis, L.; Dubacq, J. P.; Marty, Y.; Samain, J. F. and Gudin, C. (1999), Influence of growth rate on pigment and lipid composition of the microalga Isochrysis aff. galbana clone T. isso. J. Apl. Phy. 6, 315- 22.

Sipaúba-Tavares, L. H. and Rocha, O. (2001), Produção de plâncton (fitoplâncton e zooplâncton) para alimentação de organismos aquáticos. Rimaeditora, São Carlos.
Southgate, P. C.; Beer, A. C.; Duncan, P. F. and Tamburri, R. (1998), Assessment of nutritional value of three species of tropical microalgae, dried Tetraselmis and a yeast-based diet for larvae of the blacklip pearl oyster, Pinctada margaritifera (L.). Aquacul. 162, 247-257.

Sukenik, A. and Whanon, R. (1991), Biochemical quality of marine unnicellular algae with special emphasis on lipid composition: I. Isochrysis galbana. Aquacul. 97, 61-72.

Valenzuela-Espinoza, E.; Millán Núnez, R. and Núnez Cebrero, F. (2002), Protein, carbohydrate, lipid and chlorophyll $a$ content in Isochrysis aff. galbana (clone T-Iso) cultured with a low cost alternative to the $f / 2$ medium. Aquacul. Eng. 25, 207-216.

Webb, K. L. and Chu, F. E. (1983), Phytoplankton as a food source for bivalve larvae. In- Pruder, G. D. Langdon, C., Conklin, D. (ed.) Biochemical and physiological approaches to shellfish nutrition. Proceedings of the Second International conference on Aquaculture Nutrition, Louisiana State University, L. A., pp. 272-291.

Whyte, J. N. C. (1987), Biochemical composition and energy content of six species of phytoplankton used in mariculture of bivalves. Aquacul. 60, 231-241.

Yamashita C. and Magalhães P. M. S. (1984), Meios de Cultura para a Alga Chaetoceros gracilis, Boletim de Pesquisa n. 7, EMPARN, Rio Grande do Norte.

Yemm, E. W. and Cocking, E. C. (1955), The determination of aminoacids with ninhydrin. Analsyt. 80, 209-213.

Yemm, E. W. and Wills, A. J. (1954), The estimation of carbohydrates by anthrone. Bioch. J. 57, 508-514. 
PÁGINA

EM

BRANCO 